\title{
PERANCANGAN SISTEM PENDUKUNG KEPUTUSAN UNTUK PEMILIHAN PEMASOK NATA DE COCO DENGAN METODE TECHNIQUE FOR ORDER PREFERENCE BY SIMILARITY TO IDEAL SOLUTION (TOPSIS)
}

\author{
Dian Eko Hari Purnomo \\ Program Studi Teknik Industri, Fakultas Teknik, Universitas Sarjanawiyata Tamansiswa \\ dian.eko.hari.p@gmail.com
}

\begin{abstract}
Abstrak
PT. XYZ merupakan suatu perusahaan manufaktur yang memproduksi nata de coco potongan. Konsumen dari produk nata de coco potongan adalah perusahaan makanan seperti PT.Garuda food Sidoarjo, PT. Sinar Mas Kudus, PT. Borobudur Semarang dan lain-lain. PT. XYZ mempunyai dua jenis yaitu pemasok kontrak dan pemasok tidak kontrak. Saat ini, di perusahaan dalam melakukan pemilihan pemasok tidak kontrak menjadi pemasok kontrak terkadang mengalami kesulitan. Kesulitan terebut terjadi karena belum adanya kriteria yang secara rinci dapat dipergunakan untuk pemilihan pemasok. Sehingga pada penelitian ini akan berusahaan menemukan kriteria-kriteria yang berpengaruh dalam pemilihan pemasok. Pengolahan data pada penelitian ini menggunakan metode Technique for Order Preference by Similarity to Ideal Solution (TOPSIS). Selain itu, model yang telah dibuat akan diimplementasikan menjadi suatu Sistem Pendukung Keputusan (SPK). Kriteria yang dapat mempengeruhi pemilihan pemasok adalah jumlah total, jumlah total kualitas satu, jumlah total kualitas dua, jumlah total nata rusak, jumlah pengiriman maksimal, jumlah maksimal kualitas satu, jumlah maksimal kualitas dua, jumlah maksimal rusak, jumlah pengiriman minimal, jumlah minimal kualitas satu, jumlah minimal kualitas dua, jumlah minimal rusak, kerutinan, harga kualitas satu dan harga kualitas dua. Di samping itu, berdasarkan hasil pengujian Sistem Pendukung Keputusan (SPK) yang telah dibuat diperoleh kesimpulan bahwa sistem yang telah dibuat dapat dipergunakan nantinya oleh PT. XYZ.
\end{abstract}

Kata kunci : Pemilihan Pemasok, TOPSIS dan SPK

\section{PENDAHULUAN}

PT. XYZ merupakan suatu perusahaan manufaktur yang memproduksi nata de coco potongan. PT. XYZ mempunyai beberapa bagian penting diantaranya adalah bagian produksi, bagian pergudangan, dan bagian pengiriman. Pada bagian pergudangan terdapat bagian yang mengurusi pemasok. Permintaan yang terus meningkat mengakibatkan sistem produksi perusahaan tidak mampu untuk memenuhi permintaan tersebut. Sehingga diperlukan adanya pemasok bahan baku berupa pemasok lembaran untuk memenuhi permintaan konsumen. Diberbagai perusahaan manufaktur, persentase ongkos material bisa mencapai antara 40\%-70\% dari ongkos sebuah produk jadi (Pujawan, 2005). Untuk itu perusahaan membeli bahan baku setengah jadi dari pemasok. Permasalahan mulai muncul ketika perusahaan akan memilih pemasok kontrak. Pihak perusahaan kesulitan dalam melakukan penilai terhadap pemasok yang akan dipilih menjadi pemasok kontrak. Hal ini, terjadi karena pihak perusahaan belum mempunyai kriteria-kriteria yang dapat digunakan untuk menilai pemasok. Salah satu faktor kesuksesan sebuah perusahaan adalah pemilihan pemasok (Gencer dan Gurpinar, 2007). Dapat dikatakan pemilihan pemasok adalah salah satu aktivitas penting pada bagian pengadaan untuk mencapai keunggulan bersaing (Amid dkk, 2011). Selain itu, pihak perusahaan belum menggunakan suatu metode tertentu untuk pemilihan pemasok kontrak. Pemilihan pemasok adalah permasalahan multi kriteria dimana setiap kriteria yang digunakan mempunyai kepentingan yang berbeda dan informasi mengenai hal tersebut tidak diketahui secara tepat. Dalam hal ini pemilihan pemasok yang berdasarkan penawaran harga yang rendah sudah tidak efisien lagi. Untuk mendapatkan kinerja rantai pasok yang maksimal harus menggabungkan kriteria lain yang relevan dengan tujuan perusahaan $(\mathrm{Ng}, 2008)$. Tujuan dari penelitian ini adalah mengidentifikasi kriteria-kriteria yang dapat digunakan dalam pemilihan pemasok. Selain itu, akan dibuat suatu Sistem Pendukung Keputusan (SPK) yang dapat digunakan untuk pemilihan pemasok nata de coco lembaran. 


\section{METODE PENELITIAN}

Pengembangan Sistem Pendukung Keputusan untuk menentukan pemasok nata de coco mengacu kepada tahapan penelitian menggunakan pendekatan sistem sebagai berikut:

1. Mempelajari sistem pembelian nata de coco lembaran dari pemasok. Wawancara dan observasi untuk mendapatkan variable-variable keputusan penting dalam pemilihan pemasok kontrak.

2. Mengidentifikasi kriteria-kriteria yang dapat digunakan untuk penentuan pemasok nata de coco kontrak.

3. Desain sistem untuk merancang model pengambilan keputusan, basis data dan user interface pada sistem pendukung keputusan.

4. Verifikasi model menggunakan data dari PT. XYZ sebagai studi kasus.

\section{HASIL DAN PEMBAHASAN}

\section{A. Kegiatan Pembelian Nata de coco}

PT. XYZ mempunyai cara tersendiri dalam proses pembelian nata de coco lembaran dari pemasok adalah sebagai berikut:

1. Pemasok nata de coco lembaran mengirimkan nata de coco lembaran ke PT. XYZ.

2. Bagian produksi PT. XYZ khususnya pada stasiun kerja sortir A melakukan klasifikasi nata de coco lembaran menjadi tiga klasifikasi. Tiga klasifikasi tersebut adalah nata de coco lembaran kualitas satu, nata de coco lembaran kualitas dua dan nata de coco lembaran rusak. Proses pengklasifikasian ini sudah ada prosedurnya. Yang mana prosedur tersebut telah dibuat oleh bagian administrasi perusahaan berdasarkan penelitian secara langsung yang dilakukan oleh perusahaan. Rincian mengenai ketentuan klasifikasi akan dijelaskan secara rinci pada bagian berikutnya skripsi ini.

3. Setelah pengklasifikasian dilakukan penimbangan untuk masing-masing jenis klasifikasi nata de coco lembaran.

4. Dilakukan pencatatan dan pemberian bukti pengiriman kepada pemasok.

5. Proses pembayaran dilakukan dengan cara menukarkan bukti pengiriman ke bagian administrasi.

\section{B. Daftar Kriteria Yang Dapat Digunakan Untuk Pemilihan Pemasok Nata de coco}

Berikut ini adalah daftar kriteria yang dapat digunakan untuk pemilihan pemasok nata de coco, kriteria di bawah ini didasarkan pada ketentuan yang berlaku di PT. XYZ saat ini (Purnomo dan Susetyo, 2016; Pramudyo dan Purnomo, 2012).

Tabel 1. Daftar Kriteria Berdasarkan Ketentuan Yang Berlaku

\begin{tabular}{|c|c|c|c|c|c|c|}
\hline No. & Kode & Kriteria & Penjelasan & $\begin{array}{c}\text { Jenis } \\
\text { Kriteria } \\
\end{array}$ & Satuan & Bobot \\
\hline 1 & $\mathrm{C} 1$ & $\begin{array}{l}\text { Jumlah } \\
\text { Total }\end{array}$ & $\begin{array}{l}\text { Jumlah total pengiriman nata de } \\
\text { coco lembaran }\end{array}$ & $\begin{array}{c}\text { Keuntungan } \\
(+)\end{array}$ & $\begin{array}{l}\text { Kilogra } \\
\mathrm{m}(\mathrm{Kg})\end{array}$ & 4 \\
\hline 2 & $\mathrm{C} 2$ & $\begin{array}{l}\text { Jumlah } \\
\text { Total } \\
\text { Kualitas 1 }\end{array}$ & $\begin{array}{l}\text { Semakin tinggi jumlah total nata } \\
\text { de coco lembaran yang memenuhi } \\
\text { syarat maka semakin baik }\end{array}$ & $\begin{array}{c}\text { Keuntungan } \\
(+)\end{array}$ & $\begin{array}{l}\text { Kilogra } \\
\mathrm{m}(\mathrm{Kg})\end{array}$ & 3 \\
\hline 3 & $\mathrm{C} 3$ & $\begin{array}{c}\text { Jumlah } \\
\text { Total } \\
\text { Kualitas } 2\end{array}$ & $\begin{array}{l}\text { Semakin rendah jumlah total nata } \\
\text { de coco lembaran yang tidak } \\
\text { memenuhi syarat tetapi masih } \\
\text { dapat digunakan maka semakin } \\
\text { baik }\end{array}$ & Biaya (-) & $\begin{array}{l}\text { Kilogra } \\
\mathrm{m}(\mathrm{Kg})\end{array}$ & 3 \\
\hline 4 & $\mathrm{C} 4$ & $\begin{array}{c}\text { Jumlah } \\
\text { Total Rusak }\end{array}$ & $\begin{array}{l}\text { Semakin rendah jumlah total nata } \\
\text { de coco lembaran yang tidak } \\
\text { memenuhi syarat dan tidak dapat } \\
\text { digunakan maka semakin baik }\end{array}$ & Biaya (-) & $\begin{array}{l}\text { Kilogra } \\
\mathrm{m}(\mathrm{Kg})\end{array}$ & 2 \\
\hline 5 & $\mathrm{C} 5$ & $\begin{array}{c}\text { Jumlah } \\
\text { Pengiriman }\end{array}$ & $\begin{array}{l}\text { Semakin tinggi jumlah pengiriman } \\
\text { nata de coco lembaran maksimal }\end{array}$ & $\begin{array}{c}\text { Keuntungan } \\
(+)\end{array}$ & $\begin{array}{l}\text { Kilogra } \\
\mathrm{m}(\mathrm{Kg})\end{array}$ & 5 \\
\hline
\end{tabular}




\begin{tabular}{|c|c|c|c|c|c|c|}
\hline No. & Kode & Kriteria & Penjelasan & $\begin{array}{c}\text { Jenis } \\
\text { Kriteria } \\
\end{array}$ & Satuan & Bobot \\
\hline & & Maksimal & maka semakin baik & & & \\
\hline 6 & C6 & $\begin{array}{l}\text { Jumlah } \\
\text { Maksimal } \\
\text { Kualitas } 1\end{array}$ & $\begin{array}{l}\text { Semakin tinggi jumlah maksimal } \\
\text { nata de coco lembaran yang } \\
\text { memenuhi syarat maka semakin } \\
\text { baik }\end{array}$ & $\begin{array}{c}\text { Keuntungan } \\
(+)\end{array}$ & $\begin{array}{l}\text { Kilogra } \\
\text { m (Kg) }\end{array}$ & 4 \\
\hline 7 & $\mathrm{C} 7$ & $\begin{array}{l}\text { Jumlah } \\
\text { Maksimal } \\
\text { Kualitas } 2\end{array}$ & $\begin{array}{l}\text { Semakin rendah jumlah maksimal } \\
\text { nata de coco lembaran yang tidak } \\
\text { memenuhi syarat tetapi masih } \\
\text { dapat digunakan maka semakin } \\
\text { baik }\end{array}$ & Biaya (-) & $\begin{array}{l}\text { Kilogra } \\
\text { m (Kg) }\end{array}$ & 2 \\
\hline 8 & $\mathrm{C} 8$ & $\begin{array}{l}\text { Jumlah } \\
\text { Maksimal } \\
\text { Rusak }\end{array}$ & $\begin{array}{l}\text { Semakin rendah jumlah maksimal } \\
\text { nata de coco lembaran yang tidak } \\
\text { memenuhi syarat dan tidak dapat } \\
\text { digunakan maka semakin baik }\end{array}$ & Biaya (-) & $\begin{array}{l}\text { Kilogra } \\
\text { m (Kg) }\end{array}$ & 1 \\
\hline 9 & $\mathrm{C} 9$ & $\begin{array}{l}\text { Jumlah } \\
\text { Pengiriman } \\
\text { Minimal }\end{array}$ & $\begin{array}{l}\text { Semakin tinggi jumlah } \\
\text { pengiriman nata de coco lembaran } \\
\text { minimal maka semakin baik }\end{array}$ & $\begin{array}{c}\text { Keuntungan } \\
(+)\end{array}$ & $\begin{array}{l}\text { Kilogra } \\
\text { m (Kg) }\end{array}$ & 2 \\
\hline 10 & $\mathrm{C} 10$ & $\begin{array}{l}\text { Jumlah } \\
\text { Minimal } \\
\text { Kualitas } 1\end{array}$ & $\begin{array}{l}\text { Semakin tinggi jumlah minimal } \\
\text { nata de coco lembaran yang } \\
\text { memenuhi syarat maka semakin } \\
\text { baik }\end{array}$ & $\begin{array}{c}\text { Keuntungan } \\
(+)\end{array}$ & $\begin{array}{l}\text { Kilogra } \\
\text { m (Kg) }\end{array}$ & 4 \\
\hline 11 & $\mathrm{C} 11$ & $\begin{array}{l}\text { Jumlah } \\
\text { Minimal } \\
\text { Kualitas } 2\end{array}$ & $\begin{array}{l}\text { Semakin rendah jumlah minimal } \\
\text { nata de coco lembaran yang tidak } \\
\text { memenuhi syarat tetapi masih } \\
\text { dapat digunakan maka semakin } \\
\text { baik }\end{array}$ & Biaya (-) & $\begin{array}{l}\text { Kilogra } \\
\text { m (Kg) }\end{array}$ & 2 \\
\hline 12 & $\mathrm{C} 12$ & $\begin{array}{l}\text { Jumlah } \\
\text { Minimal } \\
\text { Rusak }\end{array}$ & $\begin{array}{l}\text { Semakin rendah jumlah minimal } \\
\text { nata de coco lembaran yang tidak } \\
\text { memenuhi syarat dan tidak dapat } \\
\text { digunakan maka semakin baik }\end{array}$ & Biaya (-) & $\begin{array}{l}\text { Kilogra } \\
\text { m (Kg) }\end{array}$ & 1 \\
\hline 13 & $\mathrm{C} 13$ & Kerutinan & $\begin{array}{l}\text { Semakin sering pengiriman nata } \\
\text { de coco lembaran maka semakin } \\
\text { baik }\end{array}$ & $\begin{array}{c}\text { Keuntungan } \\
(+)\end{array}$ & - & 5 \\
\hline 14 & $\mathrm{C} 14$ & $\begin{array}{c}\text { Harga } \\
\text { Kualitas } 1\end{array}$ & $\begin{array}{l}\text { Semkin murah harga beli nata de } \\
\text { coco lembaran yang memenuhi } \\
\text { syarat maka semakin baik }\end{array}$ & Biaya (-) & $\begin{array}{l}\text { Rupiah } \\
\text { (Rp) }\end{array}$ & 4 \\
\hline 15 & $\mathrm{C} 15$ & $\begin{array}{c}\text { Harga } \\
\text { Kualitas } 2\end{array}$ & $\begin{array}{l}\text { Semkin murah harga beli nata de } \\
\text { coco lembaran yang tidak } \\
\text { memenuhi syarat tetapi masih } \\
\text { maka semakin baik } \\
\text { digunakan }\end{array}$ & Biaya (-) & $\begin{array}{l}\text { Rupiah } \\
\text { (Rp) }\end{array}$ & 3 \\
\hline
\end{tabular}

\section{Daftar Pemasok Nata de coco}

Di bawah ini adalah rincian dari daftar pemasok nata de coco yang akan dipilih berdasarkan hasil pengumpulan data dari PT. XYZ, seperti terlihat pada Tabel 2.

Tabel 2. Daftar Pemasok Nata De Coco Yang Akan Dipilih

\begin{tabular}{cll}
\hline No & Kode & Nama Pemasok \\
\hline 1 & A1 & Pemasok 1 \\
2 & A2 & Pemasok 2 \\
3 & A3 & Pemasok 3 \\
4 & A4 & Pemasok 4 \\
5 & A5 & Pemasok 5 \\
\hline
\end{tabular}




\section{Struktur Hirarki dari Kegiatan Pemilihan Pemasok Nata de coco}

Dari dua bagian sebelumnya dibuat suatu struktur hirarki dari kegiatan pemilihan Pemasok Nata de coco. Gambar struktur hirarkinya dapat dilihat pada Gambar 1.

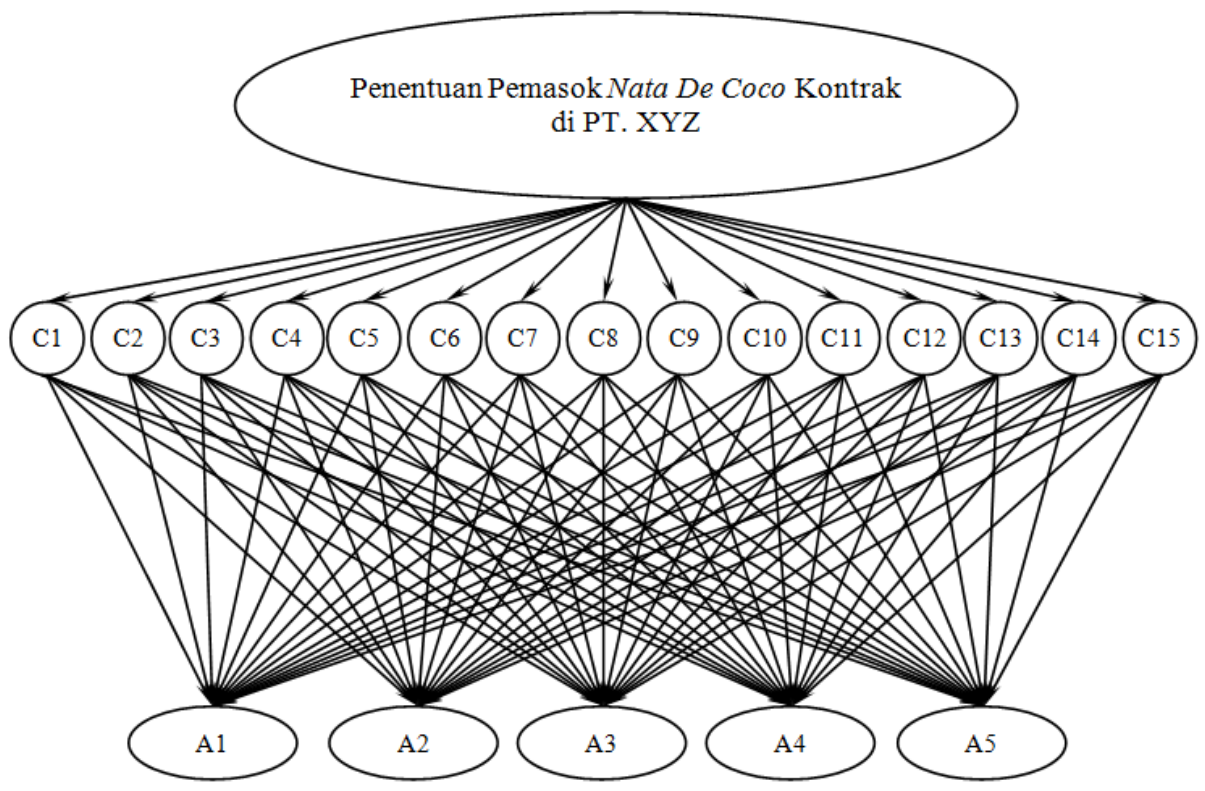

Gambar 1. Struktur Hirarki Pemilihan Pemasok Nata De Coco

\section{E. Pemodelan Sistem Pendukung Keputusan untuk Penentuan Pemasok Nata De Coco}

Pemodelan sistem yang dirancang untuk rancangan aplikasi SPK penentuan pemasok nata de coco, dirancang dalam bentuk paket komputer yang terdiri dari komponen sistem manajemen basis data, sistem manajemen model, sistem manajemen pengetahuan yang dihubungkan dengan sistem manajemen dialog yang akan memudahkan komunikasi dengan pengguna yang bersifat interaktif (Turban dkk, 2007). Konfigurasi model sistem penunjang keputusan menggambarkan komponen di dalam sistem dan keterkaitan antar komponen sistem. Konfigurasi model SPK disajikan pada gambar yang terdiri dari tiga komponen utama yaitu Sistem Manajemen Basis Model, Sistem Manajemen Basis Data dan Sistem Manajemen Dialog (Turban dkk, 2007). Model SPK ini dirancang untuk mampu menghasilkan nilai persentase dan rangking untuk masing-masing pemasok nata de coco, yang akan dipilih oleh PT. XYZ. Pemodelan sistem untuk rancangan SPK penentuan pemasok nata de coco dapat dilihat pada Gambar 1 yang terdiri dari tiga komponen utama yaitu sistem manajemen basis model, sistem manajemen basis data dan sistem manajemen dialog. 


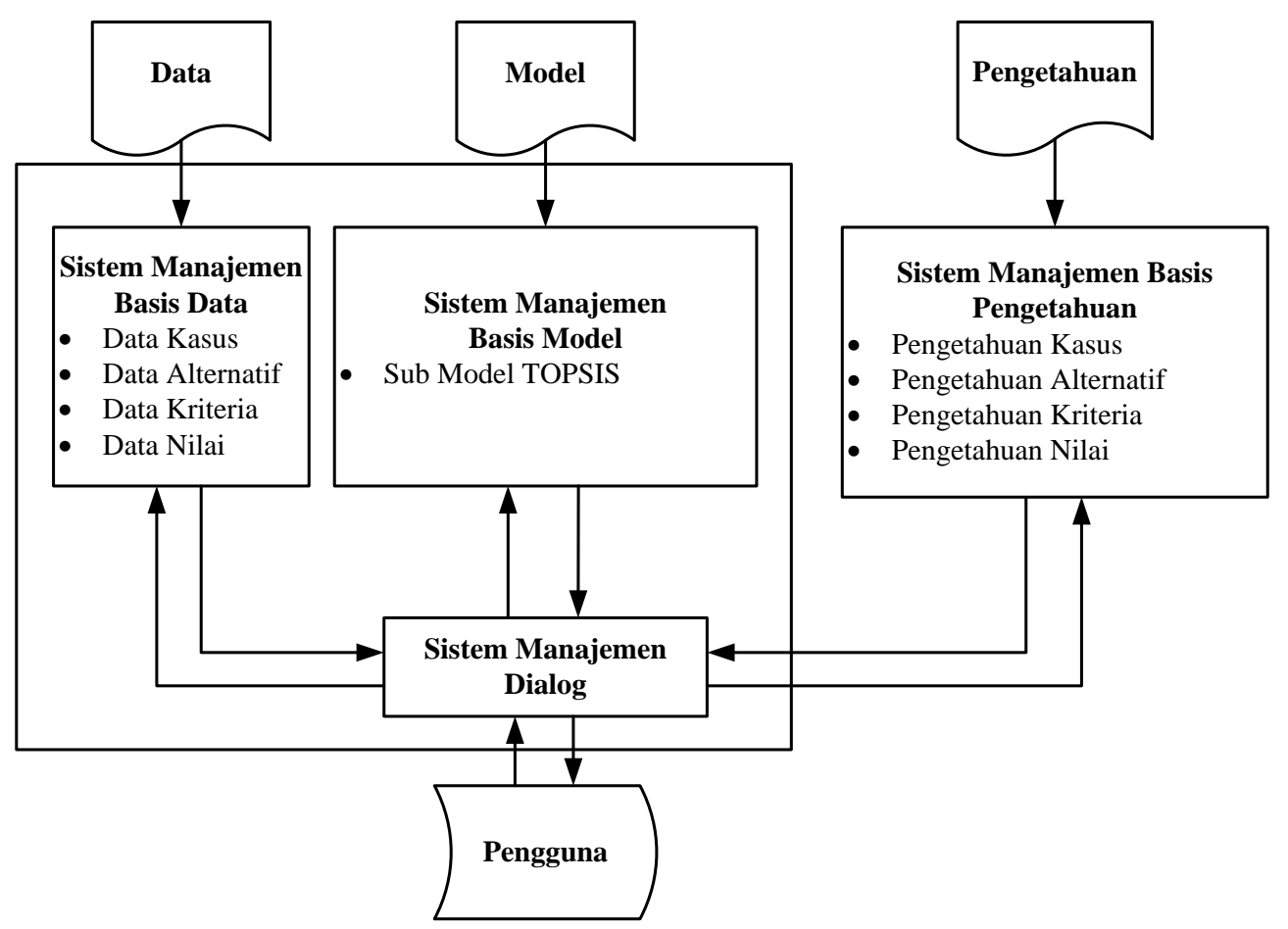

Gambar 2. Konfigurasi Sistem Pendukung Keputusan Penentuan Pemasok Nata De Coco

Diagram Alir SPK Penentuan Pemasok Nata de coco, seperti terlihat pada Gambar 3.

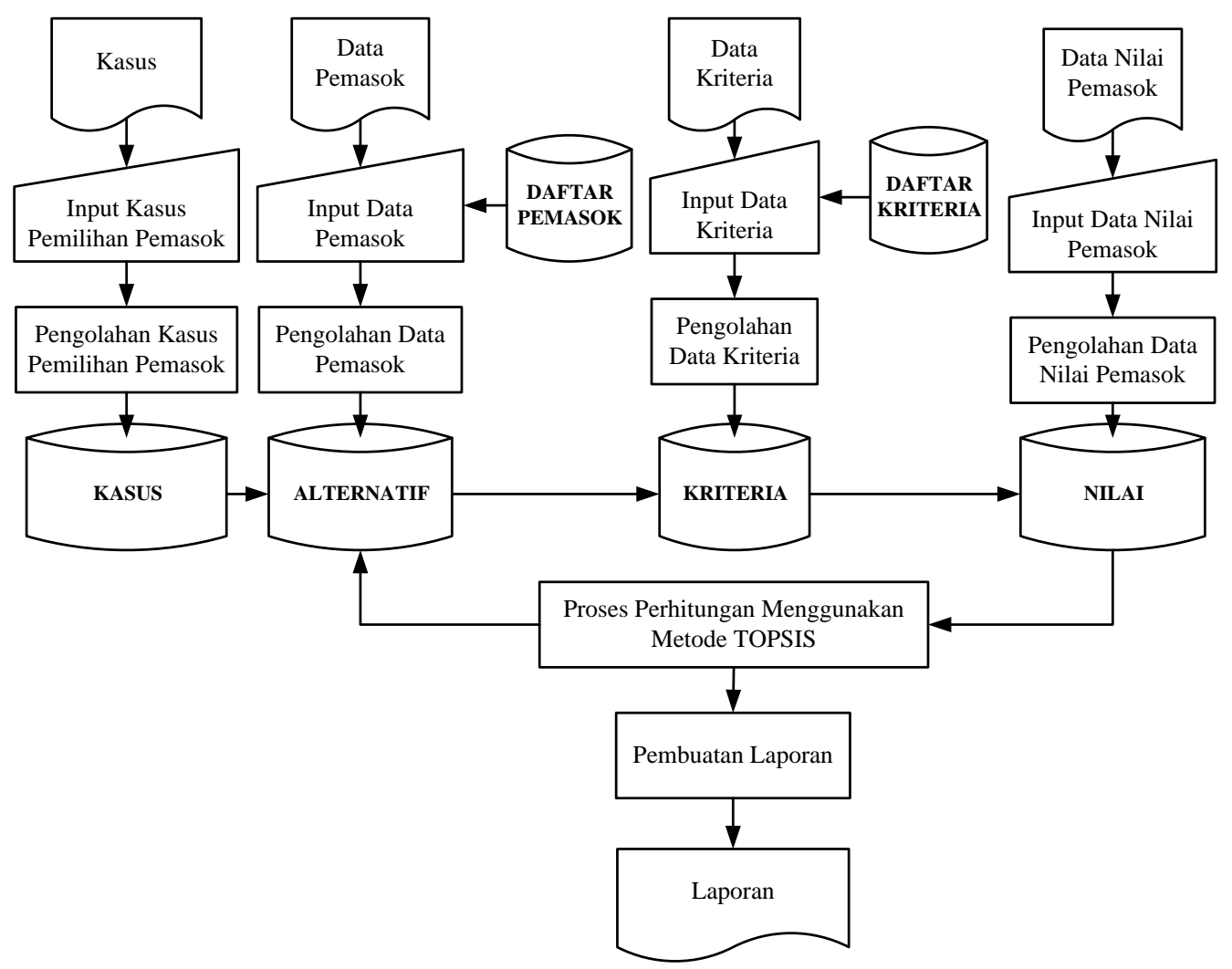

Gambar 3. Diagram Alir SPK Penentuan Pemasok Nata De Coco 


\section{F. Sistem Manajemen Basis Data}

Basis Data SPK Penentuan Pemasok Nata de coco terdiri dari basis data internal yaitu Data alternatif yang berisi daftar pemasok nata de coco dan data kriteria yang dapat digunakan untuk pemilihan pemasok. Setelah dianalisis basis data ini terdiri dari empat buah tabel yaitu input kasus, input alternatif, input kriteria, input nilai (Turban dkk, 2007).

\section{G. Perancangan Sistem Manejemen Basis Pengetahuan}

Basis Pengetahuan SPK Penentuan Pemasok Nata de coco terdiri dari berbagai tindakan yang dilakukan oleh lingkungan bisnis (misalnya konsumen, pemerintah, jasa transportasi) serta tindakan yang dilakukan PT.XYZ untuk mengantisipasinya (Turban dkk, 2007).

\section{H. Sistem Manajemen Basis Model}

1. Sistem Manajemen Dialog

Sistem Manajemen Dialog di dalam rekayasa penentuan pemasok nata de coco adalah komponen yang dirancang untuk mengatur dan mempermudah interaksi antara model (aplikasi komputer) dengan pengguna.

2. Sub Model TOPSIS

Di bawah ini adalah gambar dari diagram alir dari metode Technique for Order Preference by Similarity to Ideal Solution (TOPSIS).

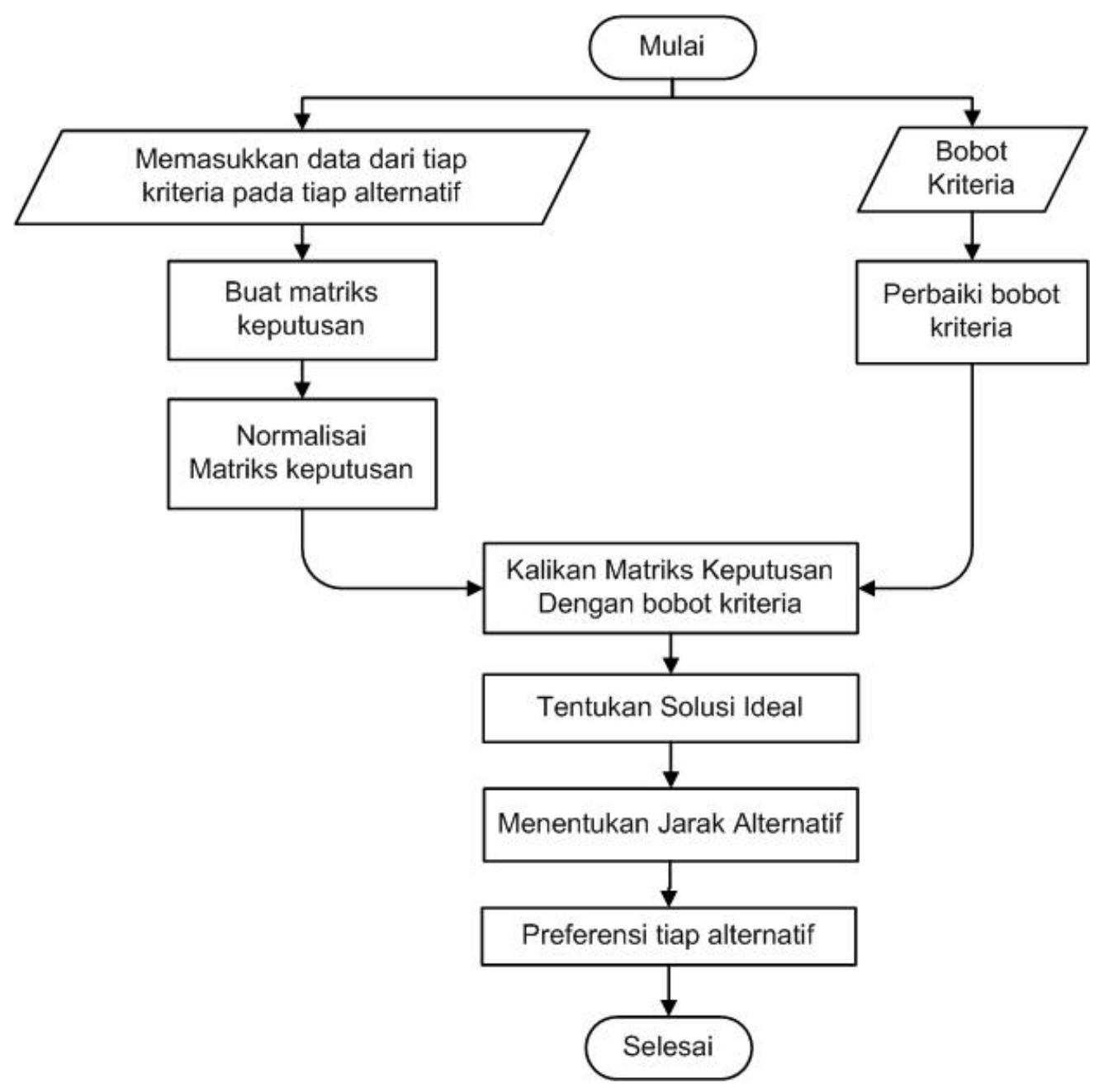

Gambar 4. Flowchart Metode TOPSIS 
Technique for Order Preference by Similarity to Ideal Solution (TOPSIS) didasarkan pada konsep di mana alternatif terpilih tidak hanya memiliki jarak terpendek dari solusi ideal positif, namun juga memiliki jarak terpanjang dari solusi ideal negatif (Hwang, 1981 dalam Kusumadewi dkk, 2006). Konsep ini banyak digunakan pada beberapa model MADM untuk menyelesaikan masalah keputusan secara praktis (Hwang,1993 dalam Kusumadewi dkk, 2006). Hal ini disebabkan: konsepnya sederhana dan mudah dipahami; komputasinya efisien; dan memiliki kemampuan untuk mengukur kinerja dari alternatif-alternatif keputusan dalam bentuk matematis sederhana. Secara umum, prosedur TOPSIS mengikuti langkah-langkah sebagai berikut (Kusumadewi dkk, 2006):

1. Membuat matriks keputusan yang ternomalisasi.

2. Membuat matriks keputusan yang ternomalisasi terbobot.

3. Menentukan matriks solusi ideal positif dan matriks solusi ideal negatif.

4. Menentukan jarak antara nilai setiap alternatif dengan matriks solusi ideal positif dan matriks solusi ideal negatif.

5. Mentukan nilai preferensi untuk setiap alternatif.

TOPSIS membutuhkan rating kinerja setiap alternatif $A_{i}$ pada setiap kriteria $C_{j}$ yang ternormalisasi, yaitu:

$$
\mathrm{r}_{\mathrm{ij}}=\frac{x_{i j}}{\sqrt{\sum_{i=1}^{m} x_{i j}^{2}}} \text {; dengan } \mathrm{i}=1,2, \ldots, \mathrm{m} ; \text { dan } \mathrm{j}=1,2, \ldots, \mathrm{n} .
$$

Solusi ideal positif $\mathrm{A}^{+}$dan solusi ideal negatif $\mathrm{A}^{-}$dapat ditentukan berdasarkan rating bobot ternormalisasi $\left(\mathrm{y}_{\mathrm{ij}}\right)$ sebagai:

Dengan

$$
\begin{aligned}
& y_{i j}=w_{i} r_{i j} ; \text { dengan } i=1,2, \ldots, m ; \text { dan } j=1,2, \ldots, n . \\
& A^{+}=\left(y_{1}^{+}, y_{2}^{+}, \ldots, y_{n}^{+}\right) ; \\
& A^{-}=\left(y_{1}^{-}, y_{2}^{-}, \ldots, y_{n}^{-}\right)
\end{aligned}
$$

$$
\begin{aligned}
& y_{j}^{+}=\left\{\begin{array}{l}
\max _{\mathrm{i}} y_{\mathrm{ij}} ; \text { jika } \mathrm{j} \text { adalah atribut keuntungan (benefit) } \\
\min _{\mathrm{i}} \mathrm{y}_{\mathrm{ij}} ; \text { jika } \mathrm{j} \text { adalah atribut biaya (cost) }
\end{array}\right. \\
& \mathrm{y}_{\mathrm{j}}^{-}=\left\{\begin{array}{l}
\min _{\mathrm{i}} \mathrm{y}_{\mathrm{ij}} ; \text { jika } \mathrm{j} \text { adalah atribut keuntungan (benefit) } \\
\max _{\mathrm{i}} \mathrm{y}_{\mathrm{ij}} ; \text { jika } \mathrm{j} \text { adalah atribut biaya (cost) }
\end{array}\right.
\end{aligned}
$$

Jarak antara alternatif $\mathrm{A}_{\mathrm{i}}$ dengan solusi ideal positif dirumuskan sebagai berikut:

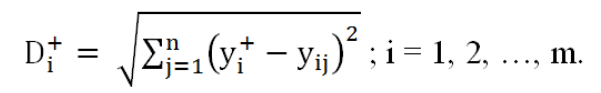

Jarak antara alternatif $A_{i}$ dengan solusi ideal negatif dirumuskan sebagai berikut:

$$
D_{i}^{-}=\sqrt{\sum_{j=1}^{n}\left(y_{i j}-y_{i}^{-}\right)^{2}} ; i=1,2, \ldots, m .
$$

Nilai preferensi untuk setiap alternatif $\left(\mathrm{V}_{\mathrm{i}}\right)$ diberikan sebagai berikut:

$$
\mathrm{V}_{\mathrm{i}}=\frac{\mathrm{D}_{\mathrm{i}}^{-}}{\mathrm{D}_{\mathrm{i}}^{-}+\mathrm{D}_{\mathrm{i}}^{+}} ; \mathrm{i}=1,2, \ldots, \mathrm{m} \text {. }
$$

Nilai $V_{i}$ yang terbesar menunjukan bahwa alternatif $A_{i}$ lebih dipilih. 


\section{Penerapan Model Pada Studi Kasus Pemilihan Pemasok}

Dari model yang telah dirancang diterapkan dalam kasus pemilihan pemasok. Data diperoleh dari perusahaan dan pakar yang telah terbiasa melakukan pemilihan pemasok nata de coco. Tabel 3 adalah ringkasan hasil perhitungan dari masingmasing metode.

Tabel 3. Matriks Awal Untuk Metode Penyelesaian TOPSIS

\begin{tabular}{cccccc}
\hline Alternatif & C1 & C2 & C3 & $\ldots$ & C15 \\
\hline Bobot & $\mathbf{0 , 0 8 9}$ & $\mathbf{0 , 0 6 7}$ & $\mathbf{0 , 0 6 7}$ & $\ldots$ & $\mathbf{0 , 0 4 4}$ \\
Pemasok 1 & 10300 & 6000 & 4000 & $\ldots$ & 1500 \\
Pemasok 2 & 10200 & 7000 & 3000 & $\ldots$ & 1000 \\
Pemasok 3 & 10200 & 6000 & 4000 & $\ldots$ & 1000 \\
Pemasok 4 & 11700 & 5500 & 6000 & $\ldots$ & 500 \\
Pemasok 5 & 8200 & 5000 & 3000 & $\ldots$ & 1500 \\
\hline
\end{tabular}

Tabel 4. Matriks Ternomalisasi Untuk Metode Penyelesaian TOPSIS

\begin{tabular}{lccccc}
\hline Alternatif & C1 & C2 & C3 & $\ldots$ & C15 \\
\hline Pemasok 1 & 0,452 & 0,452 & 0,431 & $\ldots$ & 0,577 \\
Pemasok 2 & 0,448 & 0,527 & 0,323 & $\ldots$ & 0,385 \\
Pemasok 3 & 0,448 & 0,452 & 0,431 & $\ldots$ & 0,385 \\
Pemasok 4 & 0,514 & 0,414 & 0,647 & $\ldots$ & 0,192 \\
Pemasok 5 & 0,360 & 0,377 & 0,323 & $\ldots$ & 0,577 \\
\hline
\end{tabular}

Tabel 5. Matriks Terbobot Untuk Metode Penyelesaian TOPSIS

\begin{tabular}{cccccc}
\hline Alternatif & C1 & C2 & C3 & $\ldots$ & C15 \\
\hline Pemasok 1 & 0,040 & 0,030 & 0,029 & $\ldots$ & 0,038 \\
Pemasok 2 & 0,040 & 0,035 & 0,022 & $\ldots$ & 0,026 \\
Pemasok 3 & 0,040 & 0,030 & 0,029 & $\ldots$ & 0,026 \\
Pemasok 4 & 0,046 & 0,028 & 0,043 & $\ldots$ & 0,013 \\
Pemasok 5 & 0,032 & 0,025 & 0,022 & $\ldots$ & 0,038 \\
\hline
\end{tabular}

Tabel 6. Solusi Ideal Positif

\begin{tabular}{cccccc}
\hline Alternatif & $\mathbf{C 1}$ & $\mathbf{C 2}$ & $\mathbf{C 3}$ & $\ldots$ & $\mathbf{C 1 5}$ \\
\hline Pemasok 1 & 0,040 & 0,030 & 0,029 & $\ldots$ & 0,038 \\
Pemasok 2 & 0,040 & 0,035 & 0,022 & $\ldots$ & 0,026 \\
Pemasok 3 & 0,040 & 0,030 & 0,029 & $\ldots$ & 0,026 \\
Pemasok 4 & 0,046 & 0,028 & 0,043 & $\ldots$ & 0,013 \\
Pemasok 5 & 0,032 & 0,025 & 0,022 & $\ldots$ & 0,038 \\
$\left(\mathbf{A}^{+}\right)$ & $\mathbf{0 . 0 4 6}$ & $\mathbf{0 . 0 3 5}$ & $\mathbf{0 . 0 2 2}$ & $\mathbf{\ldots}$ & $\mathbf{0 , 0 1 3}$ \\
\hline
\end{tabular}

Tabel 7. Solusi Ideal Negatif

\begin{tabular}{cccccc}
\hline Alternatif & $\mathbf{C 1}$ & $\mathbf{C 2}$ & $\mathbf{C 3}$ & $\ldots$ & $\mathbf{C 1 5}$ \\
\hline Pemasok 1 & 0,040 & 0,030 & 0,029 & $\ldots$ & 0,038 \\
Pemasok 2 & 0,040 & 0,035 & 0,022 & $\ldots$ & 0,026 \\
Pemasok 3 & 0,040 & 0,030 & 0,029 & $\ldots$ & 0,026 \\
Pemasok 4 & 0,046 & 0,028 & 0,043 & $\ldots$ & 0,013 \\
Pemasok 5 & 0,032 & 0,025 & 0,022 & $\ldots$ & 0,038 \\
$\left.\mathbf{( A}^{-}\right)$ & $\mathbf{0 , 0 3 2}$ & $\mathbf{0 , 0 2 5}$ & $\mathbf{0 , 0 4 3}$ & $\mathbf{.}$ & $\mathbf{0 , 0 3 8}$ \\
\hline
\end{tabular}


Tabel 8. Hasil Akhir Metode Penyelesaian TOPSIS

\begin{tabular}{cccccc}
\hline Alternatif & D+ & D- & V & Persentase & Ranking \\
\hline Pemasok 1 & 0,03626 & 0,05127 & 0,58576 & $19,427 \%$ & 5 \\
Pemasok 2 & 0,03963 & 0,03858 & 0,64868 & $21,285 \%$ & 1 \\
Pemasok 3 & 0,03205 & 0,04993 & 0,59254 & $19,443 \%$ & 4 \\
Pemasok 4 & 0,02987 & 0,05782 & 0,60954 & $20,001 \%$ & 2 \\
Pemasok 5 & 0,05217 & 0,03844 & 0,60476 & $19,844 \%$ & 3 \\
& Total & & $\mathbf{2 , 7 7 1 7 0}$ & $\mathbf{1 0 0 \%}$ & \\
\hline
\end{tabular}

\section{J. Implementasi SPK}

Berikut ini adalah gambaran dari SPK yang telah dikembangkan.

\section{Bagian Kasus}

Di bawah ini adalah antarmuka untuk SPK bagian kasus atau bisa disebut bagian penentuan tujuan (gambar 5).

\section{Bagian Alternatif}

Di bawah ini adalah antarmuka untuk SPK bagian alternative (gambar 6).

\section{Bagian Kriteria}

Di bawah ini adalah antarmuka untuk SPK bagian nilai (gambar 7).

\section{Bagian Nilai}

Di bawah ini adalah antarmuka untuk SPK bagian nilai (gambar 8).

\section{Bagian Hasil Perhitungan}

Di bawah ini adalah antarmuka untuk SPK bagian hasil perhitungan (gambar 9).

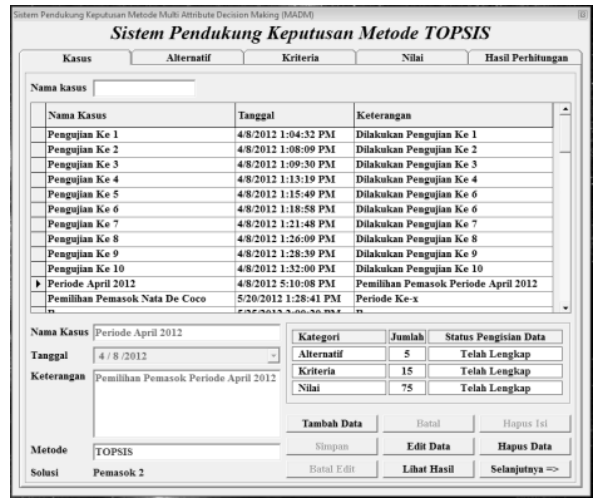

Gambar 5. Bagian Kasus

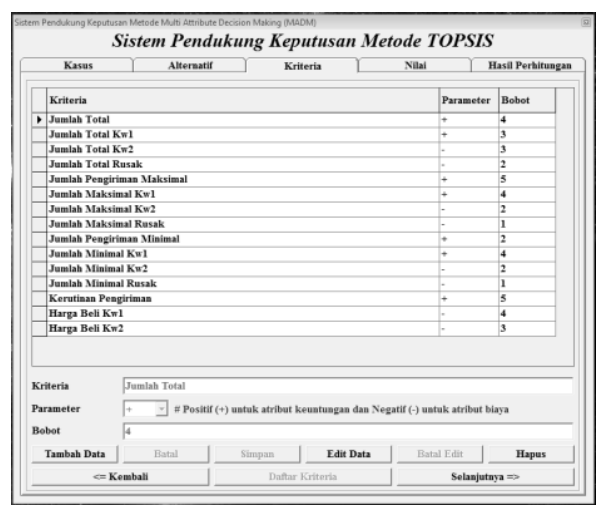

Gambar 7. Bagian Kriteria

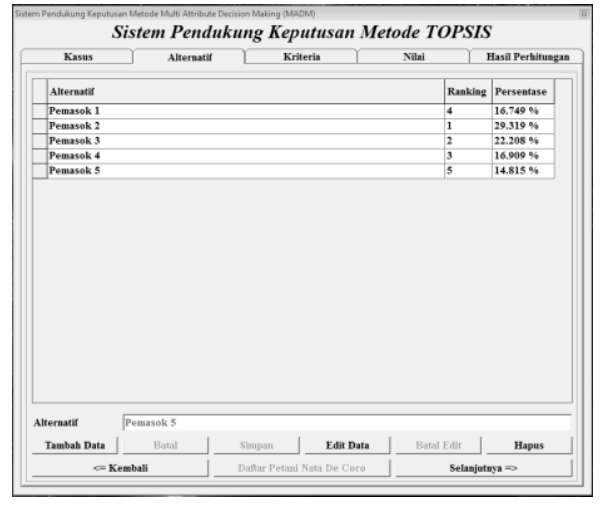

Gambar 6. Bagian Alternatif

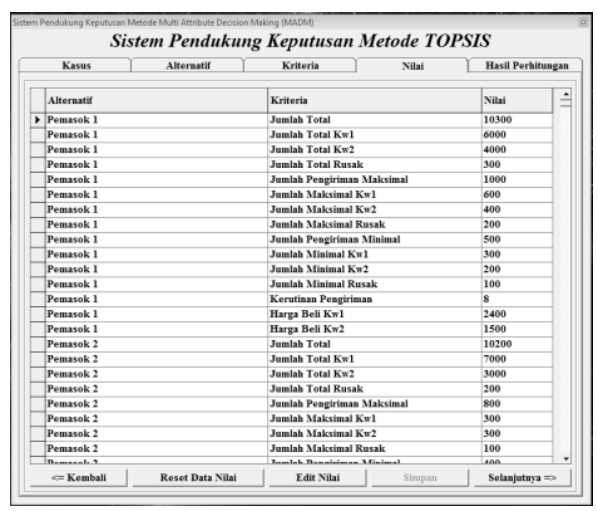

Gambar 8. Bagian Nilai 


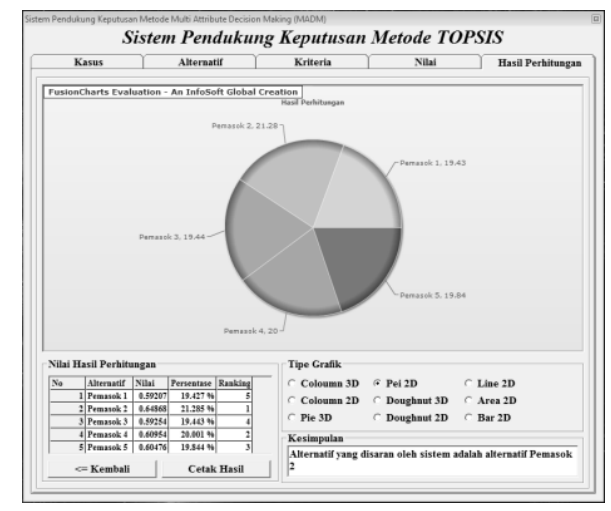

Gambar 9. Bagian Nilai

\section{KESIMPULAN}

Berdasarkan kasus yang telah diteliti, diperoleh kesimpulan sebagai berikut:

1. Dari hasil peritungan di atas pemasok yang terpilih adalah Pemasok 2, karena mempunyai nilai persentase tertinggi berdasarkan metode TOPSIS.

2. Hasil perhitungan dengan metode manual sama dengan aplikasi yang dibuat. Hal ini dapat disimpulkan bahwa aplikasi SPK yang dibuat sudah valid, sehingga siap untuk dipergunakan oleh perusahaan.

\section{DAFTAR PUSTAKA}

[1] Amid, A., Ghodsypour, S. H., dan O'Brien, C. A., 2011, Weighted Max-Min Model for Fuzzy Multi-Objective Supplier Selection in a Supply Chain, International Journal Production Economics.

[2] Fitriana, Rina dan Djatna, Taufik. 2009. Sistem Pendukung Keputusan Rantai Pasok Koperasi Pengolahan Susu X di Jawa Barat. Jakarta: Jurnal Teknik Industri Volume 10 Nomor 2, Juli 2011 Fakultas Teknologi Industri Universitas Trisakti.

[3] Fred S. Azar. 2000. Multi Attribute Decision Making: Use of Three Scoring Methods to Compare the Performance of Imaging Techniques for Breast Cancer Detection. Pennsylvania: Journal Department of Computer and Information Science University of Pennsylvania.

[4] Gencer, C., and Gurpinar, D., 2007, Analytic Network Process in Supplier Selection: A Case Study in an Electronic Firm, Journal of Applied Mathematical Modeling.

[5] Kadir, A. 2002. Pengenalan Sistem Informasi. Yogyakarta: Penerbit Andi Offset.

[6] Kusumadewi, Sri. Hartati, S. Harjoko, A. dan Wardoyo, R. 2006. Fuzzy Multi-Attribute Decision Making (FUZZY MADM). Yogyakarta: Penerbit Graha Ilmu.

[7] Ng, Wang. L., 2008, An Efficient and Simple Model for Multiple Criteria Supplier Selection Problem, European Journal of Operational Research.

[8] P. Zhou, B.W. Ang, K.L. Poh. 2006. Analysis Comparing Aggregating Methods For Constructing The Composite Environmental Index: An Objective Measure. Singapore: Journal Ecological Economics 59 Department of Industrial and Systems Engineering National University of Singapore, Hal. $305-310$.

[9] Pujawan, I Nyoman. 2005. Supply Chain Management. Surabaya: Penerbit Guna Widya.

[10] Pressman, Roger. 1992. Software Engineering a Practitioner's Approach. Singapore: McGraw-Hill,Inc.

[11] Rumaisa, Fitrah dan Nurafianti, Tanti. 2010. Sistem Pendukung Keputusan Kelulusan Ujian Saringan Masuk Jalur PMDK Berdasarkan Nilai Rata-Rata Nilai Matematika dan Bahasa Inggris. Bandung: Jurnal Konferensi Nasional: Desain dan Aplikasi Teknologi 2010 Universitas Widyatama. 
[12] Subakti, Irfan. 2002. Panduan Sistem Pendukung Keputusan. Surabaya: Diktat Jurusan Teknik Informatika Fakultas Teknologi Informasi ITS.

[13] Sulistiyo, Heri. 2010. The System Of Decision Suport For Determine Of Scholarship Receiver At SMA Negeri 6 Pandeglang. Bandung: Jurnal Fakultas Teknik dan Ilmu Komputer Universitas Komputer Indonesia.

[14] Turban, Efraim., Aronson, J.E., dan Liang, T.P., 2007, Decision Support Systems and Intelligent Systems, $7^{\text {th }}$ Edition, Prentice Hall, New Delhi.

[15] Wang, Mingxi. Liu, Shuli. Wang, Shouyang. Lai, Kin K. 2010. A Weighted Product Method For Bidding Strategies In Multi Attribute Auctions. Berlin: Journal J Syst Sci Complex, Hal. 194 - 208. 